\title{
Functionalization of acidified multi-walled carbon nanotubes for removal of heavy metals in aqueous solutions
}

\author{
A. A. Farghali ${ }^{1}$ H. A. Abdel Tawab ${ }^{2} \cdot$ S. A. Abdel Moaty ${ }^{2} \cdot$ Rehab Khaled $^{3}$
}

Received: 20 February 2017/Accepted: 11 May 2017/Published online: 24 May 2017

(C) The Author(s) 2017. This article is an open access publication

\begin{abstract}
Water pollution is a worldwide issue for the ecoenvironment and human society. Removal of various pollutants including heavy metals from the environment is a big challenge. Techniques of adsorption are usually simple and work effectively. In the current study, MWCNTs were prepared by chemical vapor deposition (CVD) of acetylene at $600{ }^{\circ} \mathrm{C} . \mathrm{Fe}-\mathrm{Co} / \mathrm{CaCO}_{3}$ catalyst/support was prepared by wet impregnation method. The crystal size of the catalyst was identified using XRD. Acidified functionalized multiwalled carbon nanotubes (MWCNT) were produced from oxidation of multi-walled carbon nanotubes by mixture of $\mathrm{H}_{2} \mathrm{O}_{2}+\mathrm{HNO}_{3}$ in a ratio of $1: 3(\mathrm{v} / \mathrm{v})$ at $25^{\circ} \mathrm{C}$. The structure and purity of synthesized functionalized CNTs were examined by TEM, $\mathrm{N}_{2}$-BET method and thermogravimetric analysis. The functional groups produced at CNTs surface were investigated using FTIR spectroscopy. Acidified functionalized MWCNTs with a high surface area of $194 \mathrm{~m}^{2} \mathrm{~g}^{-1}$ and porous structure $(17.19 \mathrm{~nm})$ were used for water treatment from harmful cations $\left(\mathrm{Pb}^{2+}, \mathrm{Cu}^{2+}, \mathrm{Ni}^{2+}\right.$ and $\left.\mathrm{Cd}^{2+}\right)$, single cation solutions and quaternary solution at different $\mathrm{pH}$ values and different times. The results were interesting because in single solutions the catalyst removed $\mathrm{Pb}^{2+}, \mathrm{Ni}^{2+}, \mathrm{Cu}^{2+}$ and $\mathrm{Cd}^{2+}$ with percentages of $93,83,78$ and $15 \%$, respectively, in $6 \mathrm{~h}$. While in quaternary
\end{abstract}

S. A. Abdel Moaty

samah.mohamed@science.bsu.edu.eg

1 Materials Science and Nanotechnology Department, Faculty of Postgraduate Studies for Advanced Sciences, Beni-Suef University, Beni Suef, Egypt

2 Materials Science Lab, Chemistry Department, Faculty of Science, Beni-Suef University, Beni Suef, Egypt

3 Department of Chemistry, Faculty of Science, Beni-Suef University, Beni Suef, Egypt solution, adsorption was more complex and the order of the adsorbed metals was as following: $\mathrm{Pb}^{2+}$ (aq) $>\mathrm{Cu}^{2+}(-$ aq) $>\mathrm{Cd}^{2+}$ (aq) $>\mathrm{Ni}^{2+}$ (aq).

Keywords Carbon nanotubes - Chemical vapor deposition $\cdot$ Functionalization $\cdot$ Adsorption

\section{Introduction}

Heavy metals are the most important pollutants in water due to their strong toxicity to plants, animals and human beings. The most heavy metals in polluted waters include $\mathrm{Hg}, \mathrm{Pb}, \mathrm{Ag}, \mathrm{Cu}, \mathrm{Cd}, \mathrm{Cr}, \mathrm{Zn}, \mathrm{Ni}, \mathrm{Co}$ and $\mathrm{Mn}$ [1]. The heavy metals cannot be degraded or destroyed as they tend to bioaccumulate in food chains. Moreover, their natural process of mineralization is very slow. Many methods are used for removing them from polluted water. The best way to get rid of these heavy metals is by immobilization of good sorbents in solutions leading to adsorption of these heavy metals on the sorbents. Many adsorbents are used for that purpose, such as activated carbon (AC) [2-4], fly ash [5], chitin [6], activated carbon cloth [7] and resins [8]. Among all of these adsorbents, the carbon nanotubes, which are one of the carbon family that possess a great potential for removing many kinds of pollutants, such as dioxin from air [9], lead [4], cadmium, zinc, fluoride [10], 1,2 dichlorobenzene [11] from water.

Studies on adsorption of heavy metals with CNTs presented in the literature are limited to few examples as shown in Table 1. The poor solubility of CNTs in most solvents limits their applications. Their poor solubility in aqueous and organic solvents and limited compatibility with polymer matrices are major drawbacks, rendering these materials incapable of achieving their full potential. 
Table 1 Reported adsorption capacities of some CNT adsorbents for some metal ion

\begin{tabular}{llll}
\hline Type of CNT & Metal ion adsorbed & Adsorptivity (\%) & References \\
\hline CNTs & $\mathrm{Pb}^{2+}$ & 17.44 & {$[40]$} \\
MWCNTs & $\mathrm{Cd}^{2+}$ & 7.4 & {$[41]$} \\
& $\mathrm{Mn}^{2+}$ & 4.8 & \\
& $\mathrm{Ni}^{2+}$ & 6.8 & {$[42]$} \\
$\mathrm{MnO}_{2} / \mathrm{CNTs}$ & $\mathrm{Pb}^{2+}$ & 78.7 & {$[43]$} \\
MWCNTs & $\mathrm{Cd}^{2+}$ & 10.8 & \\
& $\mathrm{Cu}^{2+}$ & 24.4 & {$[44]$} \\
& $\mathrm{Pb}^{2+}$ & 97.06 & \\
CNTs/Al $2 \mathrm{O}_{3}$ & $\mathrm{~Pb}^{2+}$ & 67.5 & {$[45]$} \\
& $\mathrm{Cu}^{2+}$ & 26.3 & {$[46]$} \\
MWCNTs & $\mathrm{Cd}^{2+}$ & 8.8 & This study \\
MWCNTs & $\mathrm{Co}^{2+}$ & 2.77 & \\
Functionalized MWCNTs & $\mathrm{Pb}^{2+}$ & 8.7 & \\
& $\mathrm{~Pb}^{2+}$ & 93 and 68 & \\
& $\mathrm{Ni}^{2+}$ & 82 and zero & \\
& $\mathrm{Cu}^{2+}$ & 78 and 5 & \\
& $\mathrm{Cd}^{2+}$ & 15 and 4 & \\
\hline
\end{tabular}

Hence, the functionalisation of nanotubes is extremely important, as it increases their solubility and process ability. Several modification approaches like physical, chemical or combined modifications have been exploited for their homogeneous dispersion in common solvents to improve their solubility and applications.

In the present study, MWCNTs were produced by CVD method by $\mathrm{Fe}-\mathrm{Co} / \mathrm{CaCO}_{3}$ as a catalyst at $600{ }^{\circ} \mathrm{C}$. The catalyst was characterized by XRD. Acidified functionalization of MWCNTs was done using $\mathrm{H}_{2} \mathrm{O}_{2}+\mathrm{HNO}_{3}$ in a ratio of $1: 3(\mathrm{v} / \mathrm{v})$ at $25{ }^{\circ} \mathrm{C}$. Functionalized MWCNTs were characterized by thermal analysis, FT-IR, SEM and TEM. Their capabilities to adsorb different heavy metals in single and quaternary aqueous solutions $\left(\mathrm{Pb}^{2+}, \mathrm{Cu}^{2+}, \mathrm{Cd}^{2+}\right.$ and $\mathrm{Ni}^{2+}$ ) in different $\mathrm{pH}$ [5-9] solutions and different contact time were studied as shown in Scheme 1. Our work showed high \% removal efficiency compared with previous studies as shown in Table 1. Langmuir and Freundlich isotherm models of adsorption were applied to fit the experimental data.

\section{Experimental}

\section{Materials}

Table 2 shows all materials which were used: iron nitrate, $\mathrm{Fe}\left(\mathrm{NO}_{3}\right)_{3} \cdot 9 \mathrm{H}_{2} \mathrm{O}$, SDFCL, India; cobalt nitrate, Co $\left(\mathrm{NO}_{3}\right)_{2} \cdot 4 \mathrm{H}_{2} \mathrm{O}$, and cadmium nitrate, $\mathrm{Cd}\left(\mathrm{NO}_{3}\right)_{2} \cdot 6 \mathrm{H}_{2} \mathrm{O}$, Oxford laboratory reagent, India; calcium carbonate, $\mathrm{CaCO}_{3}$, sodium hydroxide, $\mathrm{NaOH}$, PioChem Manufacturer of Laboratory Chemicals, Egypt; hydrochloric acid $\mathrm{HCl}$; hydrogen peroxide, $\mathrm{H}_{2} \mathrm{O}_{2}$; nitric acid, $\mathrm{HNO}_{3}$. All used chemicals were of analytical reagent grade and were not more purified; besides, all solutions were prepared using bi-distilled water.

\section{Preparation of the catalyst}

The catalyst/support $\left(\mathrm{Fe}-\mathrm{Co} / \mathrm{CaCO}_{3}\right)$ was prepared by impregnation method [12]. In the first step, commercial $\mathrm{CaCO}_{3}$ was milled for $10 \mathrm{~h}$ to decrease the crystallite size and increase the surface area (see Table 3). Iron and cobalt nitrates, $\left(\mathrm{Fe}\left(\mathrm{NO}_{3}\right)_{3} \cdot 9 \mathrm{H}_{2} \mathrm{O}\right)$ and $\left(\mathrm{Co}\left(\mathrm{NO}_{3}\right)_{2} \cdot 6 \mathrm{H}_{2} \mathrm{O}\right)$, were added to support $\left(\mathrm{CaCO}_{3}\right)$ with certain weight ratio (2.5:2.5:95), respectively. Milling was continued for another $2 \mathrm{~h}$. Few drops of distilled water were added to the produced catalyst/support mix making a paste just to ensure the homogeneity. The paste was then dried overnight at $120^{\circ} \mathrm{C}$ for $12 \mathrm{~h}$ and then ground well to obtain a fine powder of $\mathrm{Fe}-$ $\mathrm{Co} / \mathrm{CaCO}_{3}$ catalyst/support mixture [13].

\section{Preparation and acidification of CNTs}

CNT preparation and oxidized MWCNTs were prepared by catalytic chemical vapor deposition (CVD). The produced supported catalysts were stored in a sealed vessel and CNTs were synthesized over the catalyst. About $2 \mathrm{~g}$ of catalyst was packed in a cylindrical alumina cell. The catalyst was preheated to $600{ }^{\circ} \mathrm{C}$ in a flow of nitrogen gas ( $70 \mathrm{ml} / \mathrm{min}$ ) for $10 \mathrm{~min}$. Then acetylene gas was allowed to pass over the catalyst bed with a rate of $10 \mathrm{ml} / \mathrm{min}$ for 
Scheme 1 The application of $\mathrm{Fe}-\mathrm{Co} / \mathrm{CaCO}_{3}$ nanoparticles to produce MWCNTs for removing heavy metals from wastewater
Table 2 The specifications of the chemicals used

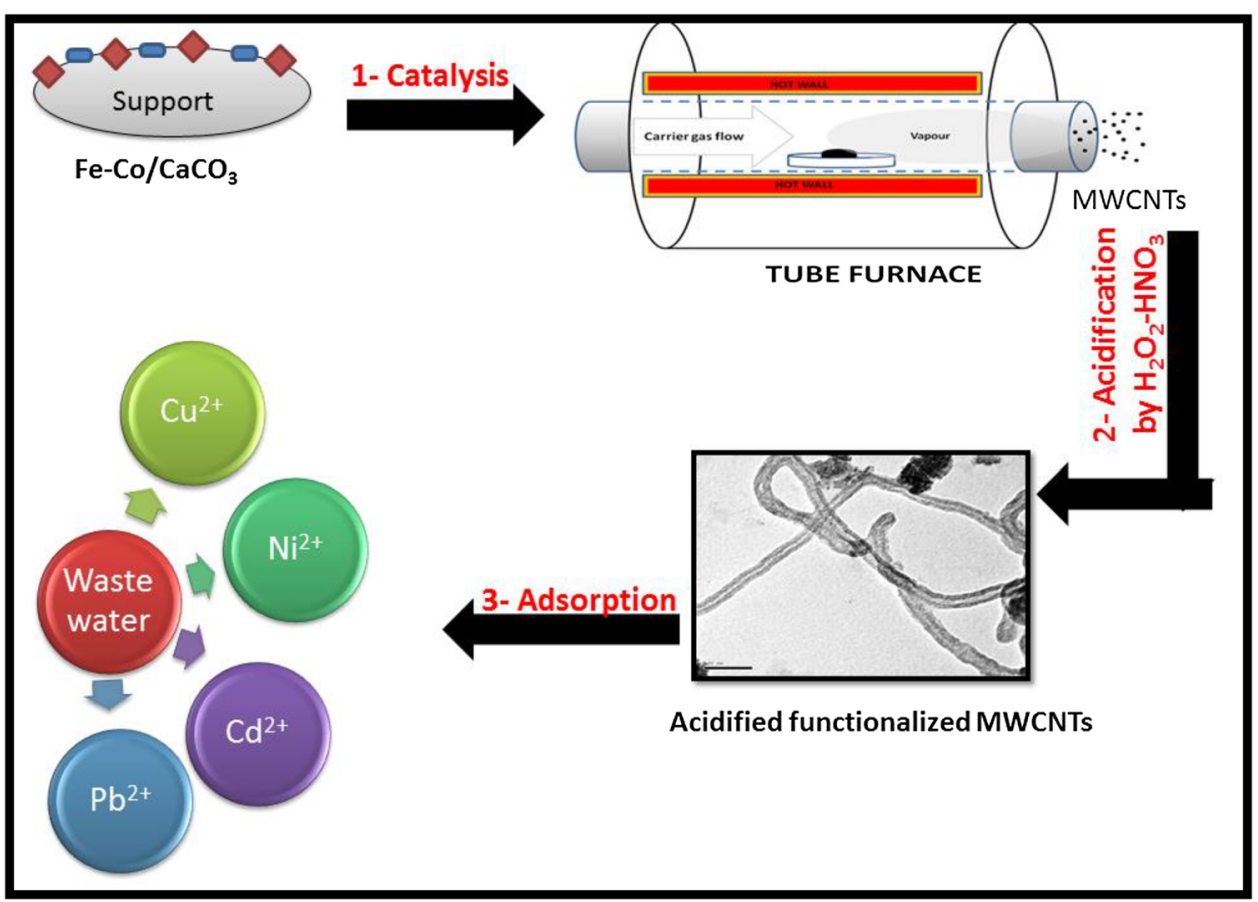

Cobalt (II) nitrates $\left(\mathrm{Co}\left(\mathrm{NO}_{3}\right)_{2} \cdot 6 \mathrm{H}_{2} \mathrm{O}\right)$

Ferric (III) nitrates $\left(\mathrm{Fe}\left(\mathrm{NO}_{3}\right)_{3} \cdot 9 \mathrm{H}_{2} \mathrm{O}\right)$

Calcium carbonate powder $\left(\mathrm{CaCO}_{3}\right)$

Acetylene gas $\left(\mathrm{C}_{2} \mathrm{H}_{2}\right)$ pure

Nitrogen $\left(\mathrm{N}_{2}\right)$ pure gas

Nitric acid $\left(\mathrm{HNO}_{3}\right)$ conc.

Hydrogen peroxide $\left(\mathrm{H}_{2} \mathrm{O}_{2}\right)$

Sodium hydroxide $(\mathrm{NaOH})$

Hydrochloric acid $(\mathrm{HCl})$ conc.

$\mathrm{Nickl}$ (II) nitrates $\left(\mathrm{Ni}\left(\mathrm{NO}_{3}\right)_{2} \cdot 6 \mathrm{H}_{2} \mathrm{O}\right.$

Lead (II) nitrates $\left(\mathrm{Pb}\left(\mathrm{NO}_{3}\right)_{2}\right)$

Cadmium chloride $\left(\mathrm{CdCl}_{2}\right)$

Copper nitrate $\left(\mathrm{Cu}\left(\mathrm{NO}_{3}\right)_{2}\right)$
(Oxford Laboratory Reagent, India) (SDFCL, India)

(PioChem)

(Commercial)

(Commercial)

(Commercial)

(PioChem)

(PioChem)

(Commercial)

(WINLAB, UK)

(WINLAB, UK)

(Oxford Laboratory Reagent, India) (WINLAB, UK)
Table 3 Ball milling conditions for preparing $\mathrm{Fe}-\mathrm{Co} / \mathrm{CaCO}_{3}$ catalyst/support

\begin{tabular}{ll}
\hline Condition & Description \\
\hline Vessel size & $7.5 \mathrm{~cm}$ diameter \\
Balls diameters & Ranged from 1.11 to $1.75 \mathrm{~cm}$ diameter \\
Materials of vessels & Stainless steel \\
Materials of balls & Porcelain \\
Ball/precipitate mass ratio & $8: 1$ mass ratio \\
Speed & $300 \mathrm{rpm}$ \\
Time & $10 \mathrm{~h}$ \\
\hline
\end{tabular}

60 min. The acetylene gas flow was stopped and the product on the alumina cell was cooled to room temperature in a flow of nitrogen gas.

MWCNTs purification process was achieved using chemical acidified oxidation method. Approximately $0.5 \mathrm{~g}$ of MWCNTs was sonicated at $25^{\circ} \mathrm{C}$ in $200 \mathrm{ml}$ of mixture of the $\mathrm{H}_{2} \mathrm{O}_{2}+\mathrm{HNO}_{3}$ in a ratio of $1: 3(\mathrm{v} / \mathrm{v})$. After $3 \mathrm{~h}$ of sonication, the acid-treated MWCNTs was diluted with $200 \mathrm{ml}$ of distilled water and filtered through a filter paper with $3 \mu \mathrm{m}$ porosity. The acid-treated MWCNTs were then washed thoroughly with distilled water until a neutral $\mathrm{pH}$ is reached and dried at $100 \pm 0.5{ }^{\circ} \mathrm{C}$ for $3 \mathrm{~h}$ [14]. 


\section{Adsorption experiments}

Analytical grade lead nitrate, nickel nitrate, cadmium chloride and copper nitrate were employed to prepare a stock solution containing $1000 \mathrm{mg} / \mathrm{l}$ for the four metal ions, which were further diluted to the required concentrations before usage. The adsorption of all cations was studied by a batch operation at $25 \pm 0.5^{\circ} \mathrm{C}[15]$.

\section{Single metal ion adsorption experiments}

In single metal ion experiments, $0.05 \mathrm{~g}$ of acidified functionalized MWCNTs was placed in $100 \mathrm{ml}$ solutions of concentration $100 \mathrm{mg} / \mathrm{l}$. Each single cation solution was adjusted at different $\mathrm{pH}$ values [5-9]. If necessary, an appropriate volume of $0.1 \mathrm{M} \mathrm{HNO}_{3}$ or $0.1 \mathrm{M} \mathrm{NaOH}$ solutions was used to adjust the $\mathrm{pH}$ of the solution. The prepared samples were shaken with an orbital shaker at a shaking speed of $200 \mathrm{rpm}$ at room temperature for $6 \mathrm{~h}$. Then solid/liquid phases were separated by filtration. The concentration of the different cations before and after adsorption was determined using atomic absorption spectrometry (Agilent Technologies 200 Series AA). The adsorbed amounts of metal ions onto the acidified functionalized MWCNTs were determined according to the following equations [1]:

$Q=\frac{\left(C_{\mathrm{o}}-C_{t}\right)}{C_{\mathrm{o}}} \times 100$,

where $Q$ is the adsorptivity (\%), $C_{\mathrm{o}}$ represents the initial concentration of metal ion and $C_{t}$ is the concentration of metal ions in $(\mathrm{mg} / \mathrm{l})$ after adsorption at time $t(\mathrm{~min})$. The amount of metal ion adsorption at equilibrium $q_{\mathrm{e}}(\mathrm{mg} / \mathrm{g})$ was determined by the following equation:

$q_{\mathrm{e}}=\frac{V\left(C_{\mathrm{o}}-C_{\mathrm{e}}\right)}{W}$.

In the equation, the equilibrium adsorption capacity of adsorbent in $\mathrm{mg}$ (metal)/g (adsorbent) represented by $q_{\mathrm{e}}, C_{\mathrm{o}}$ stands for the initial concentration of metal ions before adsorption in $\mathrm{mg} / \mathrm{l}$ and $C_{\mathrm{e}}$ is the equilibrium concentration of metal ions in $\mathrm{mg} / \mathrm{l}$. The metal ion solution volume in 1 is represented by $V$, and $W$ stands for the adsorbent weight in g [16].

\section{Competitive adsorption experiments}

To investigate the competitive adsorption of the four cations $\left(\mathrm{Pb}^{2+}, \mathrm{Cu}^{2+}, \mathrm{Ni}^{2+}\right.$ and $\left.\mathrm{Cd}^{2+}\right)$ on MWCNTs at different $\mathrm{pH}$ values [5-9], $0.05 \mathrm{~g}$ of acidified functionalized MWCNTs was added to $100 \mathrm{ml}$ solution with equal initial concentrations of the four heavy metals $(100 \mathrm{mg} / \mathrm{l})$ and the experiment was completed as previously described.
The same experimental conditions were carried out to study the effect of time by shaking the solution for $10 \mathrm{~h}$ and the filtrate concentration was measured every $2 \mathrm{~h}$ by atomic adsorption spectroscopy. The absorptivity percentage was calculated by equation [1].

\section{Characterization}

$\left(\mathrm{Fe}-\mathrm{Co} / \mathrm{CaCO}_{3}\right)$ was characterized by X-ray diffraction technique using JSX-60P JEOL diffractometer. The morphology of acidified functionalized MWCNTs was investigated by transmission electron microscope (JEOL JEM1230). The physical properties of sorbents were determined by nitrogen adsorption at $77 \mathrm{~K}$ using ASAP-2010 surface area analyzers. $\mathrm{N}_{2}$ adsorption isotherms were measured at a relative pressure range $0.0001-0.99$. The adsorption data were then employed to determine surface area using Brunauer-Emmett-Teller equation and pore size distribution (including average pore diameter and pore volume) using Barrett-Johner-Halenda equation. The functional groups on the surface sites of MWCNTs were detected by a Fourier transform infrared spectrum (model FT/IR-6100 type A). The carbon content of the sorbents was determined by a thermogravimetric analyzer (model Labsys TG-DSC $50 \mathrm{H}$ ). Heavy metals' concentrations were determined by atomic adsorption spectrometer (model ZEISS-AA55, Germany).

\section{Results and discussion}

\section{Characterizations of synthesized materials}

Figure 1 shows the XRD patterns of the catalyst $(\mathrm{Fe}-\mathrm{Co} /$ $\mathrm{CaCO}_{3}$ ) used for the preparation of MWCNTs by CVD method and the resulting peaks indicate the presence of the following phases (1: $\mathrm{CaCO}_{3}, 2$ : $\mathrm{Fe}_{2} \mathrm{O}_{3}, 3$ : $\mathrm{CoO}$ ). $\mathrm{CaCO}_{3}$ is a non-porous support material by which the formation of amorphous carbon is suppressed during nanotubes growth and, therefore, selective formation of CNTs is promoted. Purification can be achieved in one step in which both metallic particles and catalyst support can be dissolved in $\mathrm{H}_{2} \mathrm{O}_{2}+\mathrm{HNO}_{3}$. After purification, CNTs were produced with high yield, high purity and less damage of graphitic walls.

Figure $2 \mathrm{a}, \mathrm{b}$ shows the TEM images of acidified functionalized MWCNTs. The tubes are highly long $(\sim 3 \mu \mathrm{m})$ and curved with some open tips. The images show clearly a hollow inner tube with a diameter of $3 \mathrm{~nm}$ and an outer diameter of $19 \mathrm{~nm}$. Catalyst nanoparticles were encapsulated at the ends of nanotubes, confirming a tip-growth mechanism [17]. The mixed oxide particles seem to be necessary for the growth because they are often found at 


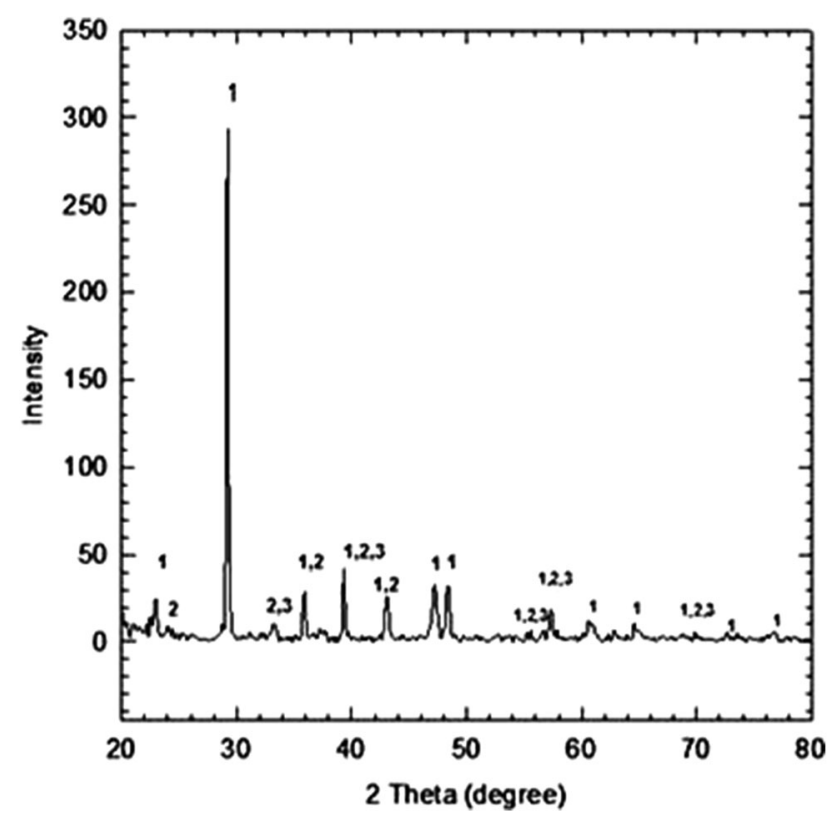

Fig. $1 \mathrm{X}$-ray diffraction patterns for $\mathrm{Fe}-\mathrm{Co} / \mathrm{CaCO}_{3}$ catalyst/support, $\mathrm{Fe}_{2} \mathrm{O}_{3}$ [1], $\mathrm{CoO}$ [2] supported on $\mathrm{CaCO}_{3}$ [3]

the tip inside the nanotube or also somewhere else in the middle of the tube as shown in Fig. 2c (marked with black spot). It is supposed that acetylene decomposes at $600{ }^{\circ} \mathrm{C}$ on the top of a supported catalyst as shown in Fig. $2 \mathrm{~d}$. The dissolved carbon diffuses in the catalyst, precipitates on the rear side and forms nanotubes. The carbon diffuses through the catalyst due to a thermal gradient formed by the heat release of the exothermic decomposition of acetylene [18].

FTIR spectra of acidified functionalized MWCNTs are shown in Fig. 3, indicating that the acid treatment generated functional groups on the surface of MWCNTs. The corresponding band close to $3438 \mathrm{~cm}^{-1}$ could be attributed to free hydroxyl groups on acidified functionalized MWCNTs surface. On the other hand, the characterized peak that appeared at $2925 \mathrm{~cm}^{-1}$ could be attributed to the stretching vibration of $\mathrm{C}-\mathrm{H}$, while the peak at $1704 \mathrm{~cm}^{-1}$ could be attributed to carboxyl groups. The peak observed at $1628 \mathrm{~cm}^{-1}$ is the $\mathrm{C}=\mathrm{C}$ stretch of the MWCNTs, while asymmetric carboxylate anions' stretch mode was shown at $1575 \mathrm{~cm}^{-1}$. The peak located at $1462 \mathrm{~cm}^{-1}$ could be attributed to carbonyl groups [19]. The absorptions at $1384 \mathrm{~cm}^{-1}$ were associated with symmetric $\mathrm{COO}^{-}$ stretching [2, 20, 21]. These produced functional groups abundantly on the external and internal surfaces of acidified functionalized MWCNTs, which can provide numerous chemical sorption sites and thus increase the ion exchange capacity for the metal ion, in other words, the hydrophilic properties of these functional groups improve the dispersity of MWCNTs in aqueous solution.

To give a further insight into the specific surface area and porosity of the as-prepared acidified functionalized MWCNTs, the BET surface area, average pore diameter and pore volume were calculated using the BJH method as shown in Table 4. The specific surface area value of the
Fig. 2 TEM images of a, b acidified functionalized MWCNTs, $\mathbf{c}$ MWCNTs after adsorption of $\mathrm{Pb}(\mathrm{II})$ and d growth model of vapor grown carbon nanotubes
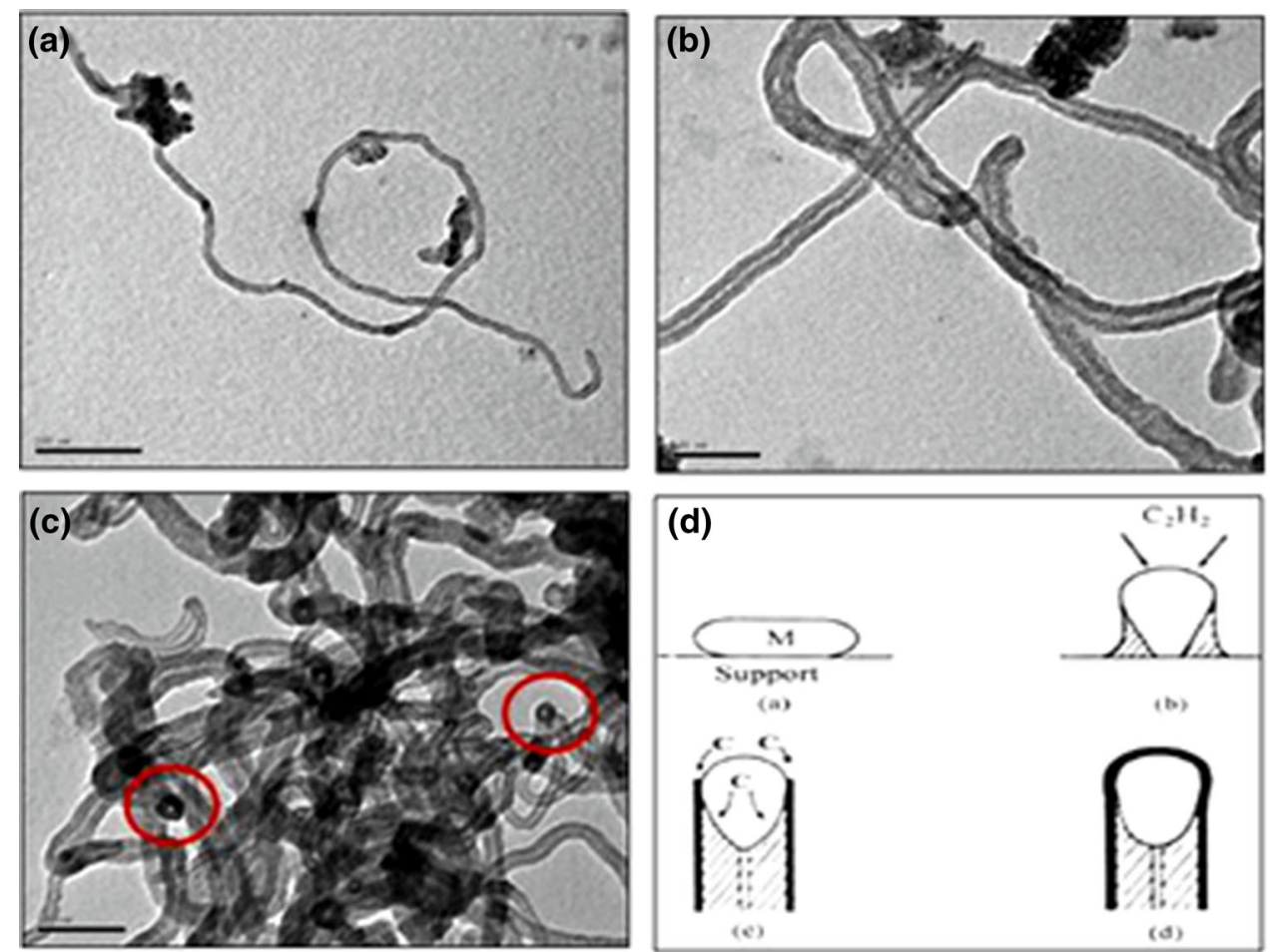


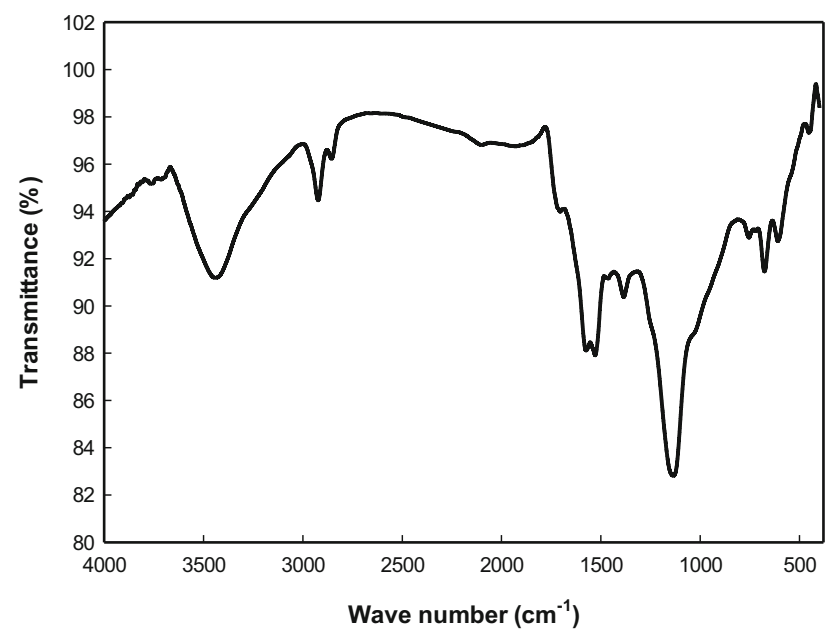

Fig. 3 FT-IR spectra of acidified functionalized MWCNTs

acidified functionalized MWCNTs is found to be $194.36 \mathrm{~m}^{2} / \mathrm{g}$, which is greater than that of prepared MWCNTs adsorbent [17], and thus adsorption capability and adsorption active sites will be increased. Removing amorphous carbon, carbon black and carbon nanoparticles introduced by CVD method leads to better dispersion of CNTs, breaks the inner tube spaces and even opens the tips partially. Figure 4 presents the adsorption-desorption isotherms of $\mathrm{N}_{2}$ on the acidified functionalized MWCNTs, and it is apparent from the adsorption and desorption curves that it exhibits a type II shape. It was observed that there is a small closed adsorption-desorption hysteresis loop with relative pressure above 0.4 , which is suggested to be due to mesopores and capillary condensation [22].

Figure 5 reveals the TGA results of acidified functionalized MWCNTs, which show temperature range for weight loss and exhibit two main weight loss regions. The first weight loss region $(\sim 10 \%)$ can be attributed to the loss of various kinds of functional groups that were produced on the surface of MWCNTs due to acidification treatment. The second region $(\sim 35 \%)$ may be attributed to the gasification of MWCNTs at which its decomposition begins at $405{ }^{\circ} \mathrm{C}$ and ends at $610{ }^{\circ} \mathrm{C}$.

Table 4 Surface area measurements for MWCNTs

\begin{tabular}{ll}
\hline Surface area $\left(\mathrm{m}^{2} / \mathrm{g}\right)$ & 194.4 \\
Total pore volume $(\mathrm{cc} / \mathrm{g})$ & 0.0835 \\
Average pore diameter $(\mathrm{nm})$ & 17.19 \\
Micro pore volume $(\mathrm{cc} / \mathrm{g})$ & 0.17 \\
\hline
\end{tabular}

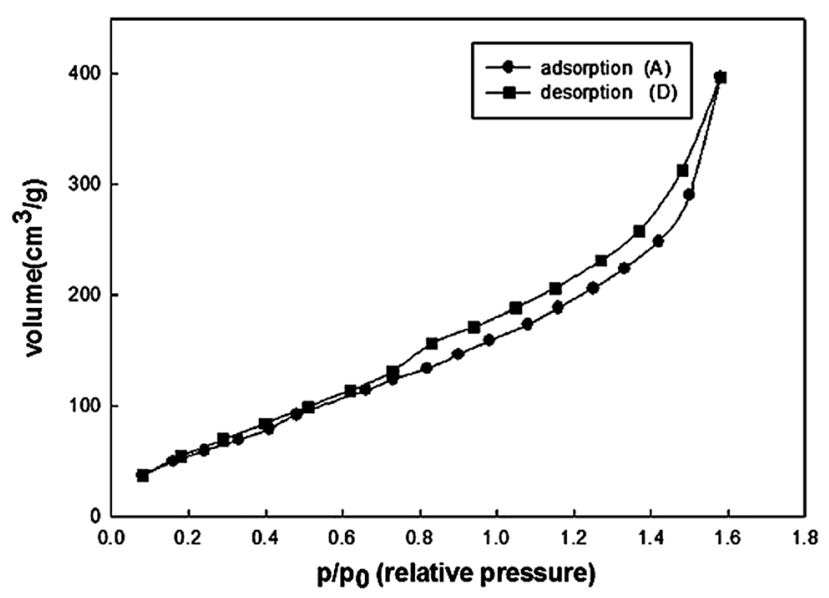

Fig. $4 \mathrm{~N}_{2}$ adsorption-desorption isotherms of acidified functionalized MWCNTs

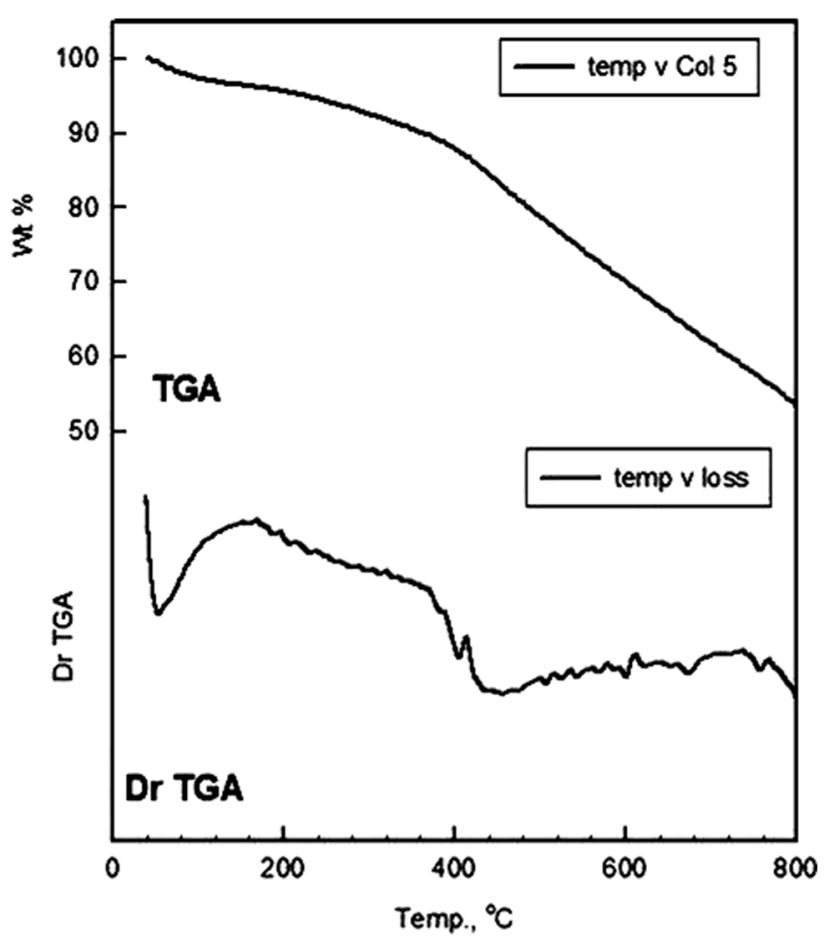

Fig. 5 TGA of acidified functionalized MWCNTs

Adsorption analysis of different metal ions $\left(\mathrm{Pb}^{2+}\right.$, $\left.\mathrm{Ni}^{2+}, \mathrm{Cu}^{2+}, \mathrm{Cd}^{2+}\right)$

\section{Adsorption isotherm of single metal ions solutions}

The adsorption equilibrium isotherm is important for describing how the adsorbate molecules distribute between the liquid and the solid phases when the adsorption process reaches an equilibrium state. The adsorption isotherms of single cation solutions of $\mathrm{Pb}^{2+}, \mathrm{Cu}^{2+}, \mathrm{Cd}^{2+}$ and $\mathrm{Ni}^{2+}$ on the acidified functionalized MWCNTs are shown in 

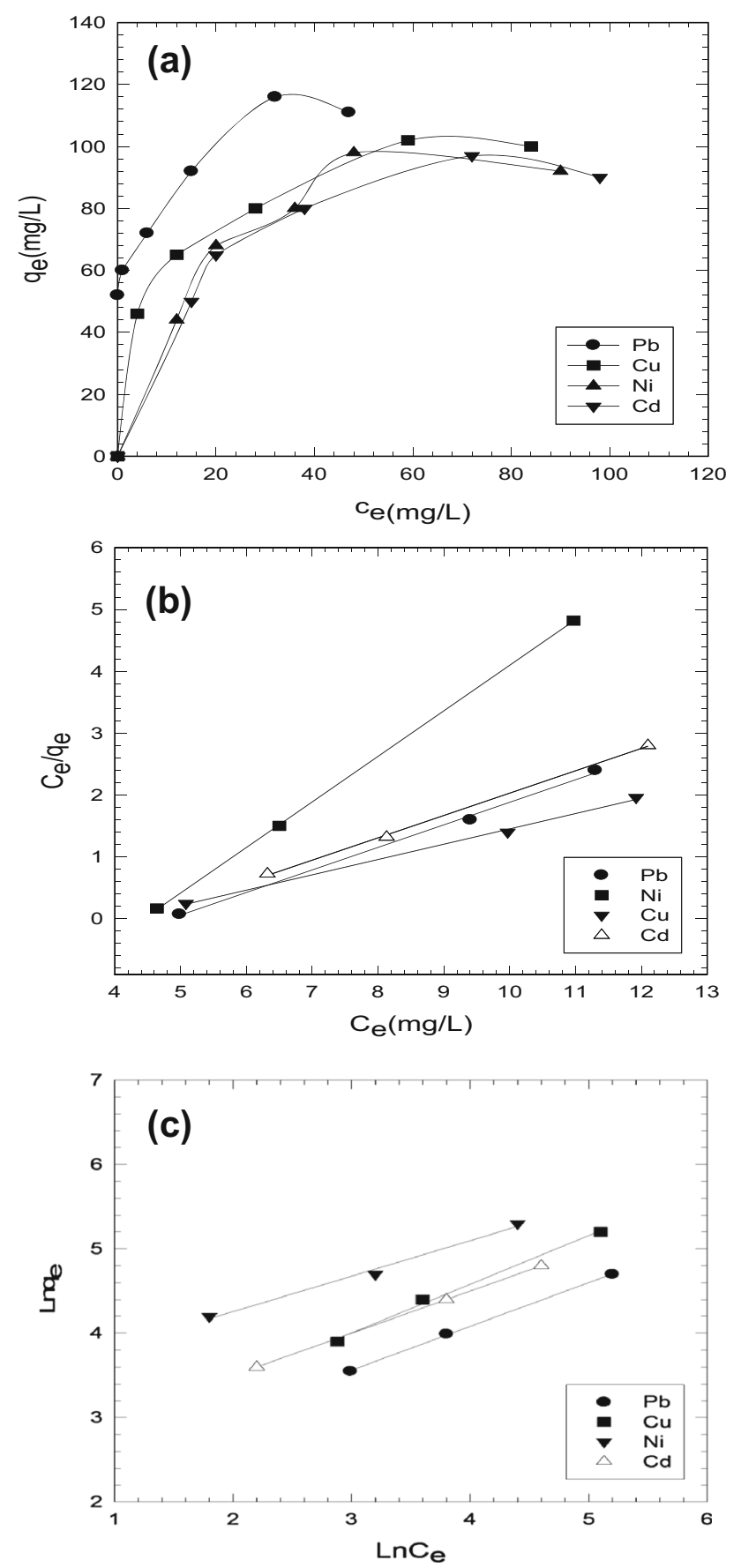

Fig. 6 Langmuir (a) and Freundlich (b) isotherms for adsorption of $\mathrm{Pb}^{2+}, \mathrm{Cu}^{2+}, \mathrm{Ni}^{2+}$ and $\mathrm{Cd}^{2+}$ onto acidified functionalized MWCNTs

Fig. 6a. Equilibrium uptake increased with heavy metal concentrations. This is a result of the increase in the driving force from the concentration gradient. In the same conditions, if the concentrations of heavy metals in solutions are higher, the active sites of the CNTs are surrounded by many more heavy metal ions and the process of adsorption would be carried out sufficiently. The experimental data for single component solutions containing $\mathrm{P}^{2+}, \mathrm{Cu}^{2+}, \mathrm{Cd}^{2+}$ and $\mathrm{Ni}^{2+}$ ions could be approximated by Langmuir and Freundlich isotherm models.

The Langmuir model assumes that there is no interaction between the adsorbate molecules and the adsorption is localized in a monolayer. The Langmuir isotherm [23] is represented by the following linear equation [3]:

$\frac{C_{\mathrm{e}}}{q_{\mathrm{e}}}=\frac{1}{\left(q_{\mathrm{o}} K_{\mathrm{L}}\right)}+\frac{1}{\left(q_{\mathrm{o}}\right)} C_{\mathrm{e}}$,

where $C_{\mathrm{e}}(\mathrm{mg} / \mathrm{l})$ is the equilibrium concentration, $q_{\mathrm{e}}(\mathrm{mg} / \mathrm{g})$ is the amount of adsorbate adsorbed per unit mass of adsorbate, and $q_{\mathrm{o}}$ and $K_{\mathrm{L}}$ are the Langmuir constants related to the adsorption capacity and the rate of adsorption, respectively. When $C_{\mathrm{e}} / q_{\mathrm{e}}$ was plotted against $C_{\mathrm{e}}$, a straight line with a slope of $1 / q_{\mathrm{o}}$ was obtained (Fig. 6b), indicating that the adsorption of the four heavy metals $\left(\mathrm{Pb}^{2+}, \mathrm{Cu}^{2+}, \mathrm{Ni}^{2+}\right.$ and $\left.\mathrm{Cd}^{2+}\right)$ on acidified functionalized MWCNTs follows the Langmuir isotherm. The Langmuir constants $K_{\mathrm{L}}$ and $q_{\mathrm{o}}$ were calculated from this isotherm and their values are listed in Table 3. Another important parameter, $R_{\mathrm{L}}$, called the separation factor or the equilibrium parameter, is evaluated in this study and determined from the following relation $[4,24]$ :

$R_{\mathrm{L}}=\frac{1}{\left[1+K_{\mathrm{L}} C_{\mathrm{o}}\right]}$,

where $K_{\mathrm{L}}$ is the Langmuir constant $(1 / \mathrm{mg})$ and $C_{\mathrm{o}}(\mathrm{mg} / \mathrm{l})$ is the highest metal ion concentration. The value of $R_{\mathrm{L}}$ indicates whether adsorption onto the MWCNTs will be unfavorable $\left(R_{\mathrm{L}}>1\right)$, linear $\quad\left(R_{\mathrm{L}}=1\right)$, favorable $\left(0<R_{\mathrm{L}}<1\right)$ or irreversible $\left(R_{\mathrm{L}}=0\right)$. $R_{\mathrm{L}}$ values for $\mathrm{Pb}^{2+}$, $\mathrm{Cu}^{2+}, \mathrm{Cd}^{2+}$ and $\mathrm{Ni}^{2+}$ were less than 1 and greater than zero indicating favorable adsorption (Table 5).

The Freundlich isotherm model is an empirical relationship describing the adsorption of solutes from a liquid to a solid surface and assumes that different sites with several adsorption energies are involved. The linear form of the Freundlich equation [5] is

$\ln q_{\mathrm{e}}=\ln K_{\mathrm{F}}+\left(\frac{1}{n}\right) \ln C_{\mathrm{e}}$,

where $q_{\mathrm{e}}$ is the amount adsorbed at equilibrium $(\mathrm{mg} / \mathrm{g})$ and $C_{\mathrm{e}}$ is the equilibrium concentration of the four metal ions. $K_{\mathrm{F}}$ and $\mathrm{n}$ are Freundlich constants, where $K_{\mathrm{F}}\left(\mathrm{mg} / \mathrm{g}(1 / \mathrm{mg})^{1 /}\right.$ ${ }^{n}$ ) is the adsorption capacity of the adsorbent and $\mathrm{n}$ gives an indication of how favorable the adsorption process is. The slope $1 / n$ ranging between 0 and 1 is a measure of adsorption intensity or surface heterogeneity. The surface becomes more heterogeneous as its value gets closer to 0 [25]. Figure 9c shows straight lines with slope $1 / n$. The adsorption of $\mathrm{Pb}^{2+}, \mathrm{Cu}^{2+}, \mathrm{Cd}^{2+}$ and $\mathrm{Ni}^{2+}$ also follows the Freundlich isotherm. Accordingly (Fig. 6c) Freundlich 
Table 5 Isotherm parameters for removal of $\mathrm{Pb}^{2+}, \mathrm{Cu}^{2+}, \mathrm{Cd}^{2+}$ and $\mathrm{Ni}^{2+}$ by acidified MWCNTs

\begin{tabular}{|c|c|c|c|c|c|}
\hline \multirow[t]{2}{*}{ Isotherms } & \multirow{2}{*}{ Parameters } & \multicolumn{4}{|c|}{ Heavy metal ions } \\
\hline & & $\mathrm{Pb}^{2+}$ & $\mathrm{Cu}^{2+}$ & $\mathrm{Ni}^{2+}$ & $\mathrm{Cd}^{2+}$ \\
\hline \multirow[t]{4}{*}{ Langmuir } & $q_{\mathrm{o}}(\mathrm{mg} / \mathrm{g})$ & 166 & 123 & 95 & 101 \\
\hline & $K_{\mathrm{L}}(1 / \mathrm{mg})$ & 0.485 & 0.384 & 0.061 & 0.560 \\
\hline & $R_{\mathrm{L}}$ & 0.017 & 0.19 & 0.020 & 0.018 \\
\hline & $R^{2}$ & 0.997 & 0.997 & 0.998 & 0.999 \\
\hline \multirow[t]{3}{*}{ Freundlich } & $K_{\mathrm{F}}\left(\mathrm{mg} / \mathrm{g}(1 / \mathrm{mg})^{1 / n}\right)$ & 42.23 & 15.12 & 37.58 & 31.96 \\
\hline & $N$ & 3.89 & 2.065 & 3.012 & 2.95 \\
\hline & $R^{2}$ & 0.999 & 0.995 & 0.990 & 0.971 \\
\hline
\end{tabular}

constants $\left(K_{\mathrm{F}}\right.$ and $\left.n\right)$ were calculated and are listed in Table 5.

\section{Effect of contact time in $\mathrm{Pb}^{2+}$ solution}

The importance of contact time comes from the need for identification of the possible rapidness of binding and removal processes of the tested metal ions by the synthesized adsorbents and obtaining the optimum time for complete removal of target metal ion. Figure 7 illustrates the effect of contact time on the adsorption of $\mathrm{Pb}^{2+}$ ions onto acidified MWCNTs at initial concentration of $100 \mathrm{mg} / \mathrm{l}$ and $\mathrm{pH}$ 9. In agreement with previous studies $[26,27]$ there is a significant increase in the adsorption capacity of $\mathrm{Pb}^{2+}$ ions as the contact time increases. The analysis of batch adsorption of metal ions was carried out in $2 \mathrm{~h}$ and the concentration of each sample was measured by atomic absorption spectroscopy; first after $2 \mathrm{~h}$, the adsorption percentage reached $84 \%$, which may be due to the fact that the initial adsorbent sites were vacant and the solute concentration gradient was high. Later, equilibrium

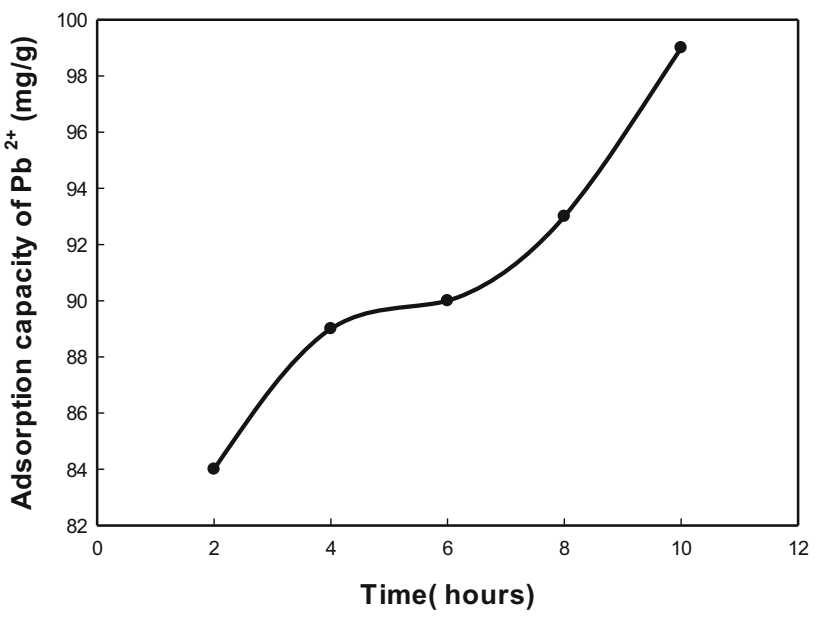

Fig. 7 The effect of contact time on adsorption of $\mathrm{Pb}^{2+}$ ions for acidified functionalized MWCNTs was achieved at a time period ranging from 6 to $8 \mathrm{~h}$ and the adsorption percentage reached to 89.8 and $90.2 \%$, respectively. Finally, a sharp increase after $8 \mathrm{~h}$ occurred and complete adsorption was achieved at $10 \mathrm{~h}$ as adsorption percentage reached $99.6 \%$ and was considered the optimum condition.

\section{Effect of MWCNTs dose}

To clarify the function of MWCNTs on adsorption capacity of lead ions, eight weights of MWCNTs $(0.1,0.15,0.2$, $0.25,0.3,0.4,0.5$ and $0.6 \mathrm{~g}$ ) were used to adsorb $\mathrm{Pb}^{2+}$ ions from aqueous solution as shown in Fig. 8. After shaking time, adsorption percentage $(\%)$ of lead ions onto MWCNTs reached sharply 13.63, 23.55, 39.13, 50.96, $72.23,73.1,73$ and 72.9 as the CNTs weight increased from $0.1,0.15,0.2,0.25,0.3,0.4,0.5$ and $0.6 \mathrm{~g}$, respectively. Therefore, the increase of MWCNTs can obviously increase the adsorption percent of $\mathrm{Pb}^{2+}$ [28-30]. Furthermore, the increase in percentage of removed lead ions with an adsorbent dosage can be attributed to an increase in the adsorbent surface which increased the availability of

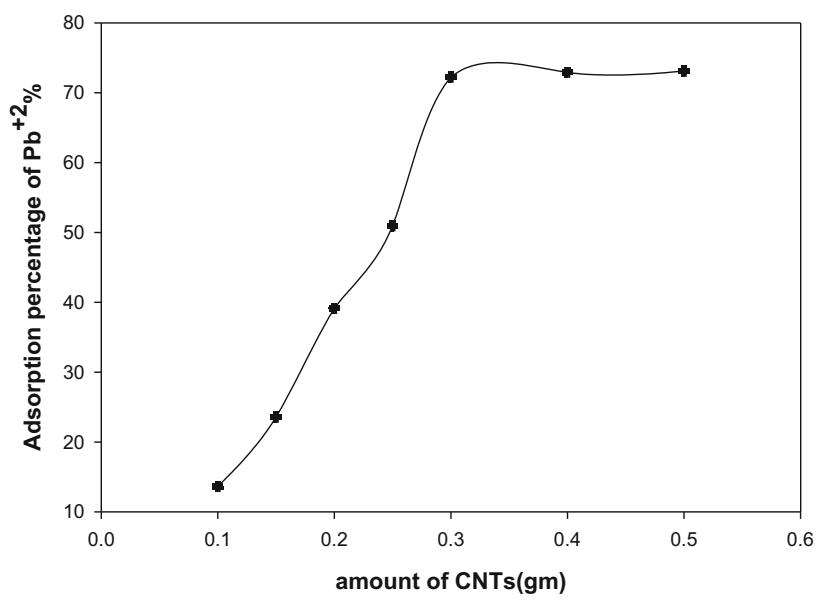

Fig. 8 Shows the effect of MWCNTs dose on the adsorption of $\mathrm{Pb}^{2+}$ 
adsorption sites; while further increase in CNT dose did not show any increase in adsorption percentage [31]. As indicated from data, there is no more adsorption up to $0.5 \mathrm{~g}$ of used CNTs.

Effect of different $\mathrm{pH}$ for different metal ions $\left(\mathrm{pb}^{2+}, \mathrm{Ni}^{2+}\right.$, $\left.\mathrm{Cu}^{2+}, \mathrm{Cd}^{2+}\right)$

Previous studies [32] showed that the $\mathrm{pH}$ of solution is the most important variable governing heavy metal ions adsorption. Figure 9 shows that at low $\mathrm{pH}$ value, the surface of the adsorbent would be closely associated with hydronium ions $\left(\mathrm{H}_{3} \mathrm{O}^{+}\right)$and hold mainly protonated sites. As a result, the surface maintains a net positive charge. So it hinders the access of the metal ions to the surface functional group. Consequently, the percentage removal of metal ions decreases as the $\mathrm{pH}$ values decreased. The positive charge on adsorbent surface, however, gradually decreases as $\mathrm{pH}$ increases, thus reducing the electrical repulsion between sorbing surface and cations. Moreover, lower $\mathrm{H}$ concentration also favors cation sorption by mass action. For example, the adsorption of bivalent cations such as $\mathrm{M}^{2+}$ on iron oxide can be written as:

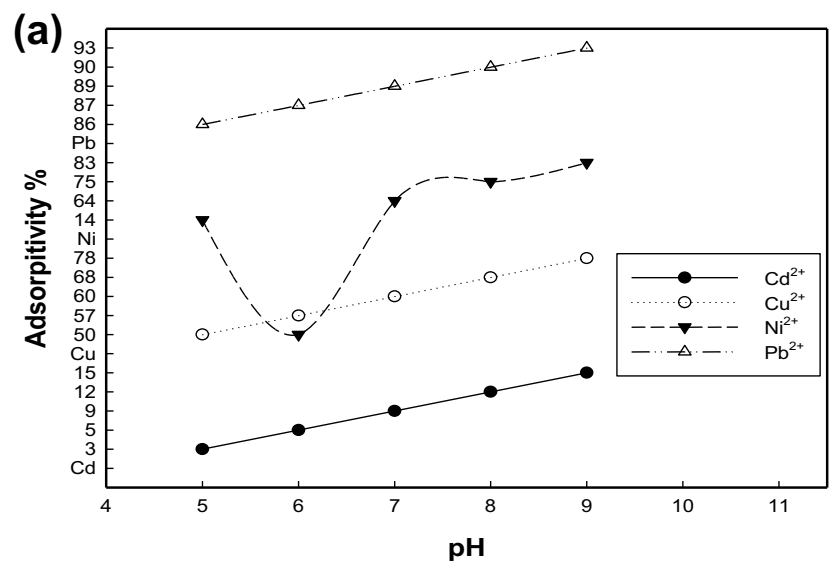

(b)

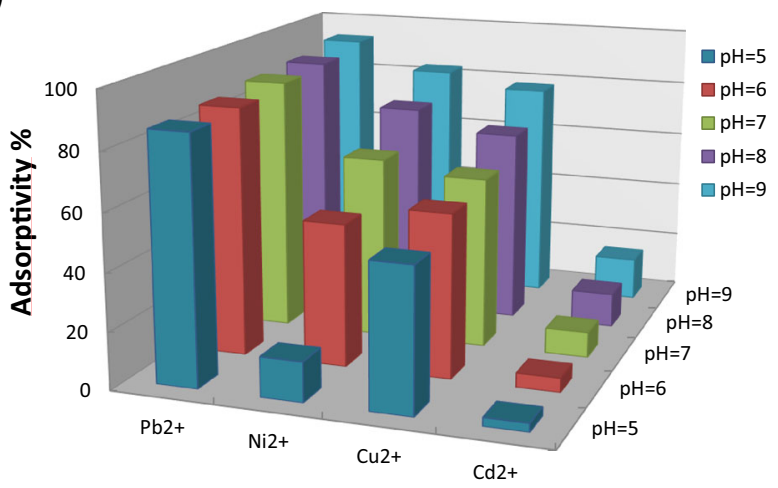

Fig. 9 The effect of different $\mathrm{pH}$ [5-9] on the adsorption uptake of metals $\mathrm{Pb}^{2+}, \mathrm{Ni}^{2+}, \mathrm{Cu}^{2+}$ and $\mathrm{Cd}^{2+}$, in single solution
$\mathrm{FeOH}_{2}^{+}+\mathrm{M}^{2+} \rightarrow \mathrm{FeOM}^{+}+2 \mathrm{H}^{+}$

Lowering $\mathrm{H}^{+}$concentration will drive this reaction toward the right-hand side and favor the sorption of $\mathrm{M}^{2+}$ by increasing $\mathrm{pH}$ [33]. That shows good agreement with Surface Complex Formation Theory (SCF), which states the following: by increasing $\mathrm{pH}$, the competition for adsorption sites between protons and metal species decreases [19]. As a result, by increasing $\mathrm{pH}$ value there are more and more attractive forces due to the presence of surface negative charges.

Effect of different metal ions on the adsorption of $\mathrm{Pb}^{2+}$ at different $\mathrm{pH}$

In a quaternary aqueous solution containing equal concentrations of $\mathrm{Pb}^{2+}, \mathrm{Cu}^{2+}, \mathrm{Cd}^{2+}$ and $\mathrm{Ni}^{2+}$ using serial $\mathrm{pH}$ values [5-9], the effect of $\mathrm{pH}$ was presented in Fig. 10 which shows that as the $\mathrm{pH}$ increase, the adsorption capacities for $\mathrm{Pb}^{2+}, \mathrm{Cu}^{2+}$ and $\mathrm{Cd}^{2+}$ increase, while $\mathrm{Ni}^{2+}$ did not show any adsorption capacity in all $\mathrm{pH}$ values. The maximum adsorption capacities reached at $\mathrm{pH} 9$ for three metals $\mathrm{Pb}^{2+}, \mathrm{Cu}^{2+}$ and $\mathrm{Cd}^{2+}$. The experimental data indicate that the adsorption affinities for the four metals take the sequence, $\mathrm{Pb}^{2+}>\mathrm{Cu}^{2+}>\mathrm{Cd}^{2+}>\mathrm{Ni}^{2+}$, which agrees with Li et al. [34]

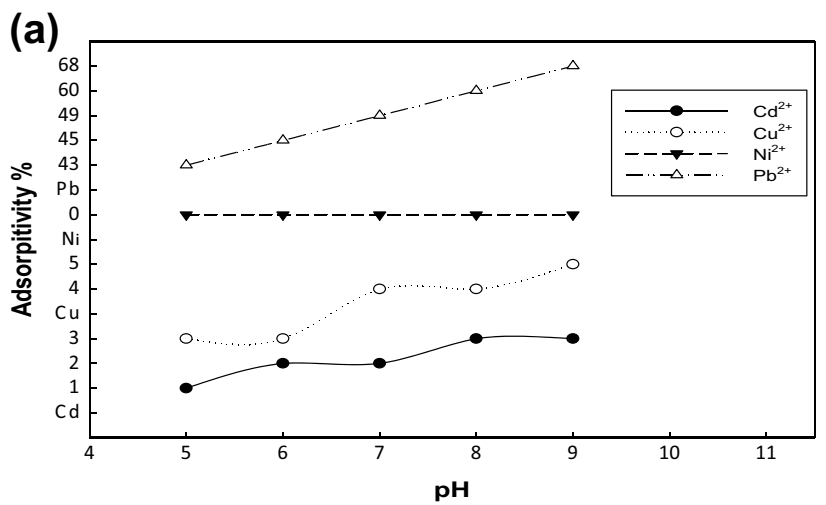

(b)

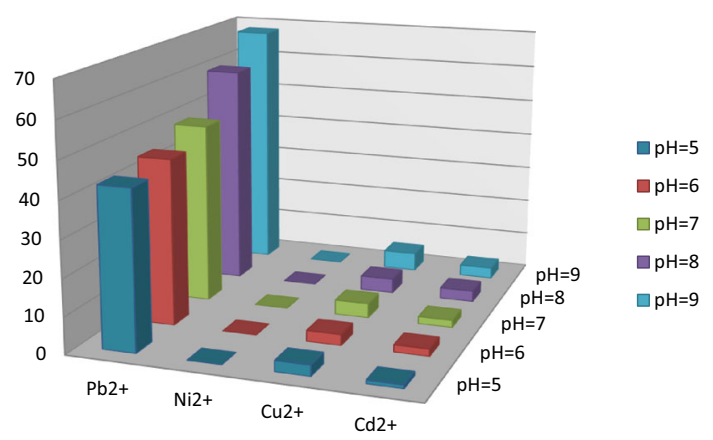

Fig. 10 The effect of different $\mathrm{pH}$ [5-9] on the adsorption uptake of metals $\mathrm{Pb}^{2+}, \mathrm{Ni}^{2+}, \mathrm{Cu}^{2+}$ and $\mathrm{Cd}^{2+}$, in multi-solution 
$\mathrm{Ni}^{2+}$ has no ability to compete the other three metal ions as it is considered to be the most weakly adsorbed species. Many studies attributed the behavior of the multi-component systems to the CNT adsorption sites [34-36] and found that $\mathrm{Pb}^{2+}$ and $\mathrm{Cu}^{2+}$ both have higher affinities more than $\mathrm{Cd}^{2+}$ and $\mathrm{Ni}^{2+}$. The competitive adsorption may be related to ion exchange and electrochemical properties of the cations. The higher the complex redox properties and ion exchange processes, the higher is the polarizability of the ion, the smaller is the value of $N / R_{\mathrm{H}}(N$ is the number of water of hydration and $\mathrm{R}_{\mathrm{H}}$ is the hydrated radius] and greater the affinity between the ions and functional groups [37]. However, there is no consensus among researchers regarding the competitive adsorption of metal ions [38, 39].

\section{Conclusions}

$\mathrm{Fe}-\mathrm{Co} / \mathrm{CaCO}_{3}$ catalyst/support was successfully prepared by wet impregnation method and characterized by XRD. The MWCNTs was synthesized in a homogeneous form by chemical vapor deposition (CVD) of acetylene on the catalyst surface at $600{ }^{\circ} \mathrm{C}$ with high density and high purity. The synthesized MWCNTs were purified by a mixture of $\mathrm{H}_{2} \mathrm{O}_{2}+\mathrm{HNO}_{3}$ in a ratio of $1: 3(\mathrm{v} / \mathrm{v})$ at $25^{\circ} \mathrm{C}$ leading to formation of functional groups on its surface. The functionalized MWCNTs were characterized using FTIR, TEM, BET and TGA. FTIR spectra of functionalized MWCNTs confirmed the presence of several functional groups. These produced functional groups can provide numerous chemical sorption sites on MWCNTs surface. From single and quaternary solutions of the four heavy metals $\left(\mathrm{Pb}^{2+}, \mathrm{Ni}^{2+}, \mathrm{Cu}^{2+}\right.$ and $\left.\mathrm{Cd}^{2+}\right)$, the following conclusions could be obtained:

1. The adsorption of $\mathrm{Pb}^{2+}, \mathrm{Ni}^{2+}, \mathrm{Cu}^{2+}$ and $\mathrm{Cd}^{2+}$ in both single and quaternary solutions increases with increase of the solution $\mathrm{pH}$.

2. The large adsorption capacity of acidified MWCNTs for the metals is mainly due to the oxygenous functional groups on its surface which could react with metals to form salt or complex deposits on the surface of MWCNTs.

3. The removal process of the metals is related to the surface chemistry of oxidized MWCNTs.

The adsorption experimental results of these heavy metals are in a good correspondence with the Langmuir and Freundlich isotherms.

Acknowledgements Special acknowledgment for Mr. Khaled Samir Hemida (MA in EFL) for helpful discussions and valuable support in English and grammar revision. The work was supported by the Faculty of Science, Materials Science Lab, Chemistry Department and Faculty of Postgraduate Studies for Advanced Sciences, Materials
Science and Nanotechnology Department, Beni-Suef University, Egypt.

Open Access This article is distributed under the terms of the Creative Commons Attribution 4.0 International License (http://crea tivecommons.org/licenses/by/4.0/), which permits unrestricted use, distribution, and reproduction in any medium, provided you give appropriate credit to the original author(s) and the source, provide a link to the Creative Commons license, and indicate if changes were made.

\section{References}

1. Wang, S., et al.: Adsorptive remediation of environmental pollutants using novel graphene-based nanomaterials. Chem. Eng. J. 226, 336-347 (2013)

2. Gabaldón, C., et al.: Single and competitive adsorption of $\mathrm{Cd}$ and $\mathrm{Zn}$ onto a granular activated carbon. Water Res. 30, 3050-3060 (1996)

3. Faur-Brasquet, C., et al.: Modeling the adsorption of metal ions $\left(\mathrm{Cu}^{2+}, \mathrm{Ni}^{2+}, \mathrm{Pb}^{2+}\right)$ onto ACCs using surface complexation models. Appl. Surf. Sci. 196, 356-365 (2002)

4. Mubarak, N., et al.: Removal of heavy metals from wastewater using carbon nanotubes. Sep. Purif. Rev. 43, 311-338 (2014)

5. Kadirvelu, K., Faur-Brasquet, C., Cloirec, P.L.: Removal of $\mathrm{Cu}$ (II), $\mathrm{Pb}$ (II), and $\mathrm{Ni}$ (II) by adsorption onto activated carbon cloths. Langmuir 16, 8404-8409 (2000)

6. Benguella, B., Benaissa, H.: Cadmium removal from aqueous solutions by chitin: kinetic and equilibrium studies. Water Res. 36, 2463-2474 (2002)

7. Bayat, B.: Comparative study of adsorption properties of Turkish fly ashes: I. The case of nickel (II), copper (II) and zinc (II). J. Hazard. Mater. 95, 251-273 (2002)

8. Diniz, C.V., Doyle, F.M., Ciminelli, V.S.: Effect of $\mathrm{pH}$ on the adsorption of selected heavy metal ions from concentrated chloride solutions by the chelating resin Dowex M-4195. Sep. Sci. Technol. 37, 3169-3185 (2002)

9. Long, R.Q., Yang, R.T.: Carbon nanotubes as superior sorbent for dioxin removal. J. Am. Chem. Soc. 123, 2058-2059 (2001)

10. Ren, X., et al.: Carbon nanotubes as adsorbents in environmental pollution management: a review. Chem. Eng. J. 170, 395-410 (2011)

11. Peng, X., et al.: Adsorption of 1,2-dichlorobenzene from water to carbon nanotubes. Chem. Phys. Lett. 376, 154-158 (2003)

12. Schwarz, J.A., Contescu, C., Contescu, A.: Methods for preparation of catalytic materials. Chem. Rev. 95, 477-510 (1995)

13. Bahgat, M., et al.: Synthesis and modification of multi-walled carbon nano-tubes (MWCNTs) for water treatment applications. J. Anal. Appl. Pyrol. 92, 307-313 (2011)

14. Mkhondo, N., Magadzu, T.: Effects of different acid-treatment on the nanostructure and performance of carbon nanotubes in electrochemical hydrogen storage. Dig. J. Nanomater. Biostruct. (DJNB) 9, 1331-1338 (2014)

15. Yuan, F., et al.: Adsorption of $\mathrm{Cd}(\mathrm{II})$ from aqueous solution by biogenic selenium nanoparticles. RSC Adv. 6, 15201-15209 (2016)

16. Kandah, M.I., Meunier, J.-L.: Removal of nickel ions from water by multi-walled carbon nanotubes. J. Hazard. Mater. 146, 283-288 (2007)

17. Abdi, Y., et al.: PECVD-grown carbon nanotubes on silicon substrates with a nickel-seeded tip-growth structure. Mater. Sci. Eng. C 26, 1219-1223 (2006)

18. Khedr, M., Bahgat, M., Abdel-Moaty, S.: Catalytic decomposition of acetylene over $\mathrm{CoFe}_{2} \mathrm{O}_{4} / \mathrm{BaFe}_{12} \mathrm{O}_{19}$ core shell 
nanoparticles for the production of carbon nanotubes. J. Anal. Appl. Pyrolysis 84, 117-123 (2009)

19. Xu, D., et al.: Removal of $\mathrm{Pb}(\mathrm{II})$ from aqueous solution by oxidized multiwalled carbon nanotubes. J. Hazard. Mater. 154, 407-416 (2008)

20. Üçer, A., Uyanik, A., Aygün, Ş.: Adsorption of $\mathrm{Cu}(\mathrm{II}), \mathrm{Cd}(\mathrm{II})$, $\mathrm{Zn}(\mathrm{II}), \mathrm{Mn}(\mathrm{II})$ and Fe(III) ions by tannic acid immobilised activated carbon. Sep. Purif. Technol. 47, 113-118 (2006)

21. Cho, H.-H., et al.: Influence of surface oxides on the adsorption of naphthalene onto multiwalled carbon nanotubes. Environ. Sci. Technol. 42, 2899-2905 (2008)

22. Bansal, R.C., Goyal, M.: Activated carbon adsorption. CRC Press, Boca Raton (2005)

23. Farghali, A., et al.: Decoration of MWCNTs with $\mathrm{CoFe}_{2} \mathrm{O}_{4}$ nanoparticles for methylene blue dye adsorption. J. Solut. Chem. 41, 2209-2225 (2012)

24. Hall, K., et al.: Pore-and solid-diffusion kinetics in fixed-bed adsorption under constant-pattern conditions. Ind. Eng. Chem. Fundam. 5, 212-223 (1966)

25. Haghseresht, F., Lu, G.: Adsorption characteristics of phenolic compounds onto coal-reject-derived adsorbents. Energy Fuels 12, 1100-1107 (1998)

26. Ernhart, C.B.: A critical review of low-level prenatal lead exposure in the human: 1. Effects on the fetus and newborn. Reprod. Toxicol. 6, 9-19 (1992)

27. Ernhart, C.B.: A critical review of low-level prenatal lead exposure in the human: 2. Effects on the developing child. Reprod. Toxicol. 6, 21-40 (1992)

28. Li, Y.H., et al.: Competitive adsorption of $\mathrm{Pb}^{2+}, \mathrm{Cu}^{2+}$ and $\mathrm{Cd}^{2+}$ ions from aqueous solutions by multiwalled carbon nanotubes. Carbon 41, 2787-2792 (2003)

29. Lu, C., Liu, C.: Removal of nickelII from aqueous solution by carbon nanotubes. J. Chem. Technol. Biotechnol. 81, 1932-1940 (2006)

30. Kabbashi, N.A., et al.: Kinetic adsorption of application of carbon nanotubes for $\mathrm{Pb}(\mathrm{II})$ removal from aqueous solution. J. Environ. Sci. 21, 539-544 (2009)

31. Rao, G.P., Lu, C., Su, F.: Sorption of divalent metal ions from aqueous solution by carbon nanotubes: a review. Sep. Purif. Technol. 58, 224-231 (2007)

32. Moaty, S.A., Farghali, A., Khaled, R.: Preparation, characterization and antimicrobial applications of $\mathrm{Zn}-\mathrm{Fe} \mathrm{LDH}$ against MRSA. Mater. Sci. Eng. C 68, 184-193 (2016)
33. Mohapatra, M., et al.: A comparative study on $\mathrm{Pb}(\mathrm{II}), \mathrm{Cd}$ (II), $\mathrm{Cu}(\mathrm{II}), \mathrm{Co}(\mathrm{II})$ adsorption from single and binary aqueous solutions on additive assisted nano-structured goethite. Int. J. Eng. Sci. Technol. 2, 89-103 (2012)

34. Li, Y.H., et al.: Adsorption of cadmium(II) from aqueous solution by surface oxidized carbon nanotubes. Carbon 41, 1057-1062 (2003)

35. Sun, Y.-P., et al.: Functionalized Carbon Nanotubes: properties and Applications. Acc. Chem. Res. 35, 1096-1104 (2002)

36. Gao, Z., et al.: Investigation of factors affecting adsorption of transition metals on oxidized carbon nanotubes. J. Hazard. Mater. 167, 357-365 (2009)

37. Trivedi, P., Axe, L., Dyer, J.: Adsorption of metal ions onto goethite: single-adsorbate and competitive systems. Colloids Surf. A 191, 107-121 (2001)

38. Gabaldon, C., et al.: Single and competitive adsorption of $\mathrm{Cd}$ and $\mathrm{Zn}$ onto a granular activated carbon. Water Res. 30, 3050-3060 (1996)

39. Ûçer, A., Uyanik, A., Aygün, A.: Adsorption of $\mathrm{Cu}(\mathrm{II}), \mathrm{Cd}(\mathrm{II})$, $\mathrm{Zn}(\mathrm{II}), \mathrm{Mn}(\mathrm{II})$ and $\mathrm{Fe}(\mathrm{III})$ ions by tannic acid immobilised activated carbon. Sep. Purif. Technol. 47, 113-118 (2006)

40. Li, Y.-H., et al.: Lead adsorption on carbon nanotubes. Chem. Phys. Lett. 357, 263-266 (2002)

41. Liang, P., et al.: Multiwalled carbon nanotubes as solid-phase extraction adsorbent for the preconcentration of trace metal ions and their determination by inductively coupled plasma atomic emission spectrometry. J. Anal. Atom. Spectrom. 19, 1489-1492 (2004)

42. Wang, H., et al.: Adsorption characteristic of acidified carbon nanotubes for heavy metal $\mathrm{Pb}$ (II) in aqueous solution. Mater. Sci. Eng. A. 466, 201-206 (2007)

43. Li, Y.-H., et al.: Competitive adsorption of $\mathrm{Pb}^{2+}, \mathrm{Cu}^{2+}$ and $\mathrm{Cd}^{2+}$ ions from aqueous solutions by multiwalled carbon nanotubes. Carbon 41, 2787-2792 (2003)

44. Hsieh, S.-H., Horng, J.-J.: Adsorption behavior of heavy metal ions by carbon nanotubes grown on microsized $\mathrm{Al}_{2} \mathrm{O}_{3}$ particles. J. Univ. Sci. Technol. 14, 77-84 (2007)

45. Pyrzyńska, K., Bystrzejewski, M.: Comparative study of heavy metal ions sorption onto activated carbon, carbon nanotubes, and carbon-encapsulated magnetic nanoparticles. Colloids Surf. A. 362, 102-109 (2010)

46. Mamba, G., et al.: Application of multiwalled carbon nanotubecyclodextrin polymers in the removal of heavy metals from water. J. App. Sci. (Faisalabad) 10, 940-949 (2010) 